\title{
The Immediate Reactions of EFL Learners towards Total Digitalization at Higher Education during the Covid-19 Pandemic
}

\section{Covid-19 Salgını Sırasında Yükseköğretimde Tam Dijitalleşmeye Yönelik YDí Öğrenenlerin Ani Tepkileri}

\author{
Erkan YÜCE*
}

Received: 20 May 2021

Research Article

Accepted: 18 November 2021

ABSTRACT: The current study focused on English as a Foreign Language (EFL) learners' immediate reactions towards total digitalization at higher education during the Covid-19 pandemic. Accordingly, the perceptions of EFL learners on online foreign language learning during the COVID-19 pandemic were investigated. After discussing the advantages and disadvantages of online foreign language classes during the pandemic from the viewpoints of the participants studying at a public university in Turkey, the study questioned whether the participants preferred online foreign language classes or traditional face-to-face foreign language classes. The study adopted the phenomenological method of qualitative design and employed open-ended questions to collect data. The data were analysed by following a bottom-up strategy, and the categories were formed inductively. The results showed that online foreign language classes had both positive and negative aspects for the learners. Additionally, it was found that more than half of the participants preferred traditional face-to-face foreign language classes to online foreign language classes.

Keywords: COVID-19 pandemic, digitalization, EFL, higher education.

ÖZ: Mevcut çalışma, Yabancı Dil olarak İngilizce (YDİ) öğrenenlerin Covid-19 salgını sırasında yükseköğretimde tam dijitalleşmeye yönelik ani tepkilerine odaklanmıştır. Bu doğrultuda, COVID-19 salgını sırasında YDİ öğrenenlerin çevrimiçi yabancı dil öğrenmeye yönelik algıları araştırılmıştır. Çalışma, Türkiye'deki bir devlet üniversitesinde okuyan katılımcıların bakış açılarından pandemi sırasında çevrimiçi yabancı dil derslerinin olumlu ve olumsuz yönlerini tartıştıktan sonra katılımcıların çevrimiçi yabancı dil derslerini mi yoksa geleneksel yüz yüze yabancı dil derslerini mi tercih ettiklerini araştırmıştır. Çalışma nitel tasarımın fenomonolojik yöntemini benimsemiş ve veri toplamak için açık uçlu sorular kullanmıştır. Veriler aşağıdan yukarıya bir strateji izlenerek analiz edilmiş ve kategoriler tümevarımla oluşturulmuştur. Sonuçlar, çevrimiçi yabancı dil derslerinin öğrenciler için hem olumlu hem de olumsuz yönleri olduğunu göstermiştir. Ayrıca, katılımcıların yarısından fazlasının geleneksel yüz yüze yabancı dil derslerini çevrimiçi yabancı dil derslerine tercih ettikleri görülmüştür.

Anahtar kelimeler: COVID-19 salgını, dijitalleşme, YDİ, yükseköğretim.

\footnotetext{
* Assoc. Prof. Dr., Aksaray University, Aksaray, Turkey, erkanyuce@aksaray.edu.tr, https://orcid.org/0000-00032716-5668
}

Citation Information

Yüce, E. (2022). The immediate reactions of EFL learners towards total digitalization at higher education during the Covid-19 pandemic. Kuramsal Eğitimbilim Dergisi [Journal of Theoretical Educational Science], 15(1), 1-15. 
COVID-19, short for "coronavirus disease 2019", started spreading from Wuhan City, Hubei Province of China on December 31, 2019, and turned into a severe pandemic in a short period all across the globe (World Health Organization [WHO], 2020a, 2020b). Besides life losses and illnesses, the precautions by governments and the efforts of authorized health institutions both locally and globally to combat this new virus affected all aspects of human life, from travel to education. Most of the countries, including Turkey, imposed strict sanctions and physical distancing measures to prevent the spread of the virus and to protect their citizens. Distancing either socially or physically requires individuals to stay at their homes to prevent the spread of the virus; accordingly, both lecturers and learners were expected to conduct classes and take responsibility from their homes (Allo, 2020). Transition to online education as a form of distance education was one of these measures, and all sorts of educational institutions, including universities, shifted to online learning overnight to decrease the negative effects of the pandemic. The Internet enabled educational institutions to continue education and rescued learners and teachers from falling behind their schedules owing to the strict distancing restrictions of the pandemic. During these difficult times, the Web technology rushed to the aid of both students and educational professionals as it did to all aspects of professional and casual lives. Before doing so, the Web technology underwent profound developments, which enabled foreign/second language education contexts to shift easily from physical classrooms in which activities are conducted in face-to-face communication to online virtual classes in which activities are accomplished either synchronously or asynchronously. With various digital tools, online language education helps instructors and learners to continue their language education without disruption during these pandemic days. In this regard, most of the learners who are habitually used to face-to-face foreign language education distantly experienced online foreign language education recently, and they hold different perceptions about the advantages and disadvantages regarding this model. At this point, revealing experiences of the foreign language learners regarding total digitalization of EFL classes at the university may highlight points that may provide insights for professionals teaching at the tertiary level. Accordingly, this study aims at revealing Turkish EFL learners' perspectives concerning online foreign language learning during the COVID19 pandemic. Three research questions of the current study are as follows:

- What are the advantages of online foreign language learning during the COVID19 pandemic?

- What are the disadvantages of online foreign language learning during the COVID-19 pandemic?

- What do you think about the applicability of online foreign language learning during the COVID-19 pandemic?

\section{Literature Review}

Although the COVID-19 has been a quite recent pandemic, which profoundly affected education contexts, many professionals in foreign/second language education contexts in different parts of the world reported research studies focusing on different aspects of online foreign/second language education during the pandemic. This part of the study summarizes some of the research studies, which are directly related to the 
focus of the current study. These studies having been carried out can be grouped under six groups, and they are:

- EFL/ESL learners' views on online language learning during the pandemic,

- EFL lecturers' views and challenges regarding online language classes during the pandemic,

- The effect of social media use in online foreign language learning during the pandemic,

- The importance of establishing virtual communities and online professional networks during the pandemic,

- The types of online tools and their impacts on learners during the pandemic,

- The experiences of EFL professionals in preparing and delivering online language classes during the pandemic.

The first of these groups dwelt on revealing EFL/ESL learners' views on online language learning during the pandemic. For example, Layali and Al-Shlowiy (2020) reviewed the ESL/EFL learners' views on e-learning in Saudi universities during the pandemic. The study analysed eight research studies in terms of learners' perceptions, benefits of e-learning, and drawbacks of e-learning. Writing quality, vocabulary learning, collaboration, and student-teacher communication were reported as benefits of e-learning, while the Internet connection was reported as a drawback of e-learning. Similarly, Allo (2020) figured out the perceptions of Indonesian EFL learners regarding online learning in the midst of the pandemic. The semi-structured interview questions were directed at the participants via a video calling application. The participants reported positive views on online language education during the pandemic. They also expressed that while Internet access helped them follow individual tasks in a physically distant way, the implementations needed improvements in terms of materials, assignments, and instructions. Harida (2020) tried to explore the views of the students on online learning during the pandemic. The results showed that the students felt unconfident, enthusiastic, and bored; and, they expected the transition to conventional classes very soon. Shahzad et al. (2020) questioned the impact of online teaching on ESL learners' behaviours. The results showed that the learners were in favour of online teaching. Likewise, Hartshorn and Mcmurry (2020) searched the effects of the COVID19 pandemic on teachers and learners at a university ESL context in the U.S. through a survey addressing stress level, English learning and teaching, and distance instruction. The results revealed that the pandemic increased the stress levels of both teachers and learners in various contexts, and the stressors stemming from the pandemic negatively affected the priorities of the participants. The results also presented that transition to online instruction from conventional classes was less challenging for the teachers than the learners, and the speaking skills of the students were less developed than their writing skills.

The second of these groups investigated EFL lecturers' views and challenges regarding online language classes during the pandemic. For example, Atmojo and Nugroho (2020) probed EFL teachers' ways of conducting EFL classes and their challenges. The teachers reflected that they carried out the classes in different ways through various platforms, either synchronously or asynchronously, in line with school policies. They also mentioned many problems stemming from students, teachers, and 
parents of the students. They noted that online learning did not accomplish the expected results due to preparation and planning. Furthermore, Lee and Bailey (2020) stated that the pandemic presented challenges in transferring classes to online education settings for the EFL instructors who are used to face-to-face communication regarding pronunciation and speaking classes when compared to the EFL instructors who are experienced in delivering online classes. They tried to reveal the benefits, challenges, and implementation strategies of EFL university lecturers with various levels of online teaching experience in South Korea. The participants with higher online teaching experience reported fewer obstacles and a wider choice of communication channels and activity types. All of the participants noted similar levels of anticipated advantages for lecturers and challenges for learners.

The third of these groups searched the effect of social media use in online foreign language learning during the pandemic. For example, Altam (2020) looked into the efficiency of social media use on EFL learners in India during the pandemic. The results informed that spending more time on social media platforms helped the learners not only to improve their language skills, especially writing skills and vocabulary knowledge but also decreased their spelling errors. Moreover, Bestari et al. (2020) researched the learners' perceptions of social media as an online learning environment during the pandemic. The participants stated that social media helped them to improve themselves concerning English grammar, writing, and vocabulary items.

The fourth of these groups focused on the importance of establishing virtual communities and online professional networks during the pandemic. For example, Lomicka (2020) focused on the importance of establishing virtual communities for language learners and suggested that social presence is very important for language learners to maintain a feeling of connectedness in virtual classrooms. Accordingly, several useful implications were provided for creating a virtual presence and engaging learners into virtual communities. Additionally, Knight (2020) addressed the issue of creating online professional networks for language educators and maintained that technical knowledge, reflective and evaluative competencies, sustained engagement, and collaboration with colleagues are the four important points for a successful online professional community.

The fifth of these groups addressed the types of online tools and their impacts on learners during the pandemic. For example, Handayani and Handayani (2020) tried to give an overview of online writing tools that can be potentially implemented in EFL writing classes at universities during the pandemic. The results indicated three online writing tools (Pro-Writing Aid, Edmodo, and Paragraph Punch) which are applicable in EFL classes. In addition, Fansury et al. (2020) searched how to implement digital content and whether it can help to enhance learner motivation and interest. The results revealed that digital contents are beneficial during the pandemic as they can be easily integrated into different online platforms flexibly, while limited web access can negatively affect learners' participation.

The last of these groups engaged in the experiences of EFL professionals in preparing and delivering online language classes during the pandemic. For example, Kanno (2020) searched the experiences of an EFL teacher in terms of developing and delivering classes in a higher education context in Japan. Peer-to-peer communication in enhancing collaborative learning in a virtual classroom was searched. The 
communicative learning spaces were created in the synchronous distance classes through digital applications. Analyses showed various types of communication in the virtual environments and the students' positive feelings towards EFL classes albeit distancing physically. Likewise, Shaaban (2020) quested teaching English as a foreign language (TEFL) lecturers' experience on e-learning during the pandemic in Gaza. The results informed that the participants need the training to enhance their skills regarding designing, developing, and planning action plans for TEFL online classes. Additionally, Yi and Jang (2020) discussed how the pandemic affected EFL contexts based on the cases of two EFL teachers in South Korea and how these teachers coped with the situation through video-based online EFL classes.

In conclusion, a number of research studies searched online foreign/second language education contexts for various purposes, as the impact of the pandemic has been profound on education contexts though it has a short history. The literature review indicated a gap regarding the research studies of online foreign language teaching during the pandemic in our country. The current study would contribute to the literature by presenting results in terms of student perspectives from an EFL education context in Turkey during the pandemic.

\section{Methodology}

\section{Research Design}

The study employed the phenomenological method of qualitative design. The qualitative inquiry focuses on understanding or exploring the definitions, characteristics, experiences, and descriptions ascribed to a problem by individuals or groups (Berg \& Lune, 2013; Creswell \& Creswell, 2018; Scott \& Morrison, 2007). To this end, openended questions were directed at the participants through an interview form. Interviewing is one of the ways through which we can understand how individuals understand their surroundings (Merriam, 2009). The results were analysed descriptively in categories by giving direct quotations from the participants (Patton, 2002).

\section{Study Group}

The $2^{\text {nd }}$ Grade students studying at a Gastronomy and Culinary Arts Department of a public university in Turkey were the participants of the study. This group was an ordinary EFL group at an average state university in the country, and it was thought that the findings reached in this group could reflect common issues related to foreign language teaching during the pandemic. Additionally, the group was one of those who regularly followed the online classes during the pandemic, which could contribute to the findings. The EFL classes were conducted in a traditional face-to-face class mode during the fall term of the 2019-2020 academic year at the department, but the classes shifted to online mode during the spring term of the 2019-2020 academic year after the pandemic. Purposeful sampling and convenient sampling techniques were followed in defining the participants. The participants were included in the study voluntarily. There were 14 male participants and 6 female participants, 20 participants in total. Their ages ranged between 20 and 25 years. 


\section{Data Collection}

The qualitative inquiry was followed in the data collection process and the researcher designed a form consisting of three open-ended questions. The questions investigated the participants' views on the advantages and disadvantages of online EFL classes during the pandemic and the participants' preferences (conventional face-to-face EFL course or online EFL classes). Due to the strict social isolation rules of the pandemic, the researcher and the participants avoided face-to-face interviews and the question form was sent to the participants via e-mails. They responded to the openended questions in a written way and sent them back in the same way to the researcher. The questions were prepared in English, and the participants were allowed to use online dictionaries to express their ideas clearly.

\section{Data Analysis}

Descriptive analysis was employed to analyze the data, and categories were formed inductively by following a bottom-up organizing strategy (Creswell \& Creswell, 2018; Thorne, 2000). Sample quotations from the participants were provided to present the views of the participants (Creswell, 2012). Additionally, each participant was put in order numerically and was also labelled with "P" (participant); for example, "P10" refers to "Participant 10". The purpose of labelling was to keep the participants" identities confidential.

\section{Trustworthiness}

Trustworthiness of the study was provided by peer review and external auditor strategies. Another peer who was familiar with the qualitative research reviewed the research processes and the data; and, then an external auditor examined the whole research process and findings to establish credibility (Creswell \& Miller, 2000).

\section{Ethical Procedures}

Ethical committee approval for this study was obtained from the Ethics Committee of Nevşehir Hacı Bektaş Veli University (Num: 2020.17.230; Date: 22.09.2020).

\section{Results}

The first research question investigated the participants' views on the advantages of online foreign language learning during the Coronavirus disease (COVID-19) pandemic. The results of the analyses revealed seven categories regarding the advantages of online foreign language learning during the pandemic, and these categories and distributions of the participants into the categories were presented in the following table (Table 1) as follows: 
Table 1

Advantages of Online Foreign Language Learning during the Pandemic

\begin{tabular}{ll}
\hline \multicolumn{1}{c}{ Categories } & \multicolumn{1}{c}{ Participants } \\
\hline Availability & $\mathrm{P} 2, \mathrm{P} 3, \mathrm{P} 5, \mathrm{P} 6, \mathrm{P} 7, \mathrm{P} 8, \mathrm{P} 9, \mathrm{P} 10, \mathrm{P} 11, \mathrm{P} 12, \mathrm{P} 14, \mathrm{P} 16, \mathrm{P} 17, \mathrm{P} 19, \mathrm{P} 20$ \\
Accessibility & $\mathrm{P} 1, \mathrm{P} 3, \mathrm{P} 5, \mathrm{P} 6, \mathrm{P} 7, \mathrm{P} 8, \mathrm{P} 11, \mathrm{P} 13, \mathrm{P} 15, \mathrm{P} 16, \mathrm{P} 17, \mathrm{P} 18, \mathrm{P} 19, \mathrm{P} 20$ \\
Cost efficiency & $\mathrm{P} 1, \mathrm{P} 2, \mathrm{P} 5, \mathrm{P} 7, \mathrm{P} 8, \mathrm{P} 10, \mathrm{P} 11, \mathrm{P} 13, \mathrm{P} 17, \mathrm{P} 18, \mathrm{P} 19$ \\
Time efficiency & $\mathrm{P} 2, \mathrm{P} 7, \mathrm{P} 8, \mathrm{P} 10, \mathrm{P} 12, \mathrm{P} 13, \mathrm{P} 14, \mathrm{P} 18$ \\
Comfort & $\mathrm{P} 2, \mathrm{P} 4, \mathrm{P} 7, \mathrm{P} 8, \mathrm{P} 10, \mathrm{P} 19$ \\
Personal speed & $\mathrm{P} 5, \mathrm{P} 13, \mathrm{P} 15, \mathrm{P} 18$ \\
Free from social pressure & $\mathrm{P} 12, \mathrm{P} 17$
\end{tabular}

According to Table 1, the categories were sequenced as availability, accessibility, cost-efficiency, time efficiency, comfort, personal speed, and free from social pressure. These seven categories were handled respectively. Considering the category of availability, fifteen participants stated that online platforms made foreign language classes available 7 days and 24 hours during the pandemic, and they did not fall behind their classes. "...we can listen to the lessons whenever we want..." (P2), "... whenever we want, we can open and watch the lessons..." (P9), and "...It is good for students that there is not a certain class hour. We can watch lessons whenever we want..." (P14) were expressions from the participants. Given the category of accessibility, 14 participants considered that online platforms made foreign language classes accessible for them, and they could easily reach the classes from their homes in different cities during the pandemic. For example, the participants said, "...we had a chance to access information quickly and easily. That is, no matter where you are physically in, whether in Nevşehir or Bahamas, you can join the distance lessons just with a click..." (P15), "...first of all you can realize yourself regardless of time and place thanks to the Internet..." (P20). Concerning the category of cost-efficiency, 11 participants claimed that online foreign language classes were cost-efficient for them during the pandemic. For example, the participants voiced that "...online classes eliminate additional expenses..." (P5), and “...the other positive side is cost. Online education costs less than traditional face-to-face education..." (P11). Related to the category of time efficiency, eight participants proclaimed that online foreign languages were time-efficient for them during the pandemic. For example, the participants expressed that "...there is no waste of time. First of all, there is no need to interrupt education in adverse weather conditions..." (P7), and “...I think the most important advantage is to save time..." (P12). Regarding the category of comfort, six participants stated that online foreign language classes were comfortable for them during the pandemic. For example, the participants said that "...You can listen to your lessons on your comfortable chair at home..." (P4), and "...First of all, students can learn at the comfort of their place..." (P10). In connection to the category of personal speed, four participants considered that online foreign language classes enabled them to follow the classes at their speeds during the pandemic. For example, the participants expressed that "...Students can study at their own paces..." (P5) and "...the student learns at his/her learning speed..." (P15). With regard to the last category, free from social pressure, two 
participants stated that online foreign language classes were free from social pressure and enabled them to communicate with teachers directly during the pandemic. For example, P12 expressed that "...It provides students who are embarrassed in a face-toface session to be more active in online lessons...", and P17 said that "...Online lessons improve communication with teachers..."

The second research question searched for the participants' views on the disadvantages of online foreign language learning during the COVID-19 pandemic. The results of the analyses revealed seven categories regarding the disadvantages of online foreign language learning during the pandemic, and these categories and distributions of the participants into the categories were presented in the following table (Table 2) as follows:

Table 2

Disadvantages of Online Foreign Language Learning during the Pandemic

\begin{tabular}{ll}
\hline \multicolumn{1}{c}{ Categories } & \multicolumn{1}{c}{ Participants } \\
\hline Lack of peer and social interaction & $\mathrm{P} 1, \mathrm{P} 5, \mathrm{P} 6, \mathrm{P} 7, \mathrm{P} 8, \mathrm{P} 9, \mathrm{P} 12, \mathrm{P} 14, \mathrm{P} 15, \mathrm{P} 16, \mathrm{P} 17, \mathrm{P} 18, \mathrm{P} 19$ \\
Tech-related problems & $\mathrm{P} 2, \mathrm{P} 3, \mathrm{P} 5, \mathrm{P} 7, \mathrm{P} 11, \mathrm{P} 12, \mathrm{P} 13, \mathrm{P} 16, \mathrm{P} 17, \mathrm{P} 19$ \\
Mode of learning & $\mathrm{P} 7, \mathrm{P} 8, \mathrm{P} 12, \mathrm{P} 15, \mathrm{P} 17, \mathrm{P} 18, \mathrm{P} 20$ \\
Ineffective feedback & $\mathrm{P} 1, \mathrm{P} 2, \mathrm{P} 7, \mathrm{P} 8, \mathrm{P} 9, \mathrm{P} 13, \mathrm{P} 14$ \\
Lack of concentration & $\mathrm{P} 2, \mathrm{P} 3, \mathrm{P} 4, \mathrm{P} 8, \mathrm{P} 14, \mathrm{P} 16$ \\
Lack of self-discipline & $\mathrm{P} 2, \mathrm{P} 6, \mathrm{P} 10, \mathrm{P} 20$ \\
Health problems & $\mathrm{P} 2, \mathrm{P} 16$
\end{tabular}

According to Table 2, the seven categories were lack of peer and social interaction, tech-related problems, mode of learning, ineffective feedback, lack of concentration, lack of self-discipline, and health problems. These seven categories were dealt with accordingly. Regarding the category of peer and social interaction, 13 participants considered that they were dissatisfied with the lack of peer and social interaction in online foreign language classes during the pandemic. For example, P1 stated, "...it is the lack of social interaction in online classes. It is harder to communicate and be understood when students and teachers do not see each other directly..." and P18 expressed that "...there is less teacher and student interaction..." Considering the category of tech-related problems, 10 participants informed that technology and Internet-related problems were among the disadvantages of online foreign language classes during the pandemic. For example, P2 said, “...Another major disadvantage of online education is that some students do not have enough equipment in terms of technology...", and P17 said that "...not everyone has enough equipment, for example, I have not got a laptop and the Internet connection..." In light of the mode of learning category, seven participants noted that online foreign language learning did not appeal to their learning styles during the pandemic. For example, P7 expressed that "...it is difficult to learn lessons only with notes. Also, education efficiency in distance education is lower than face-to-face communication...", and P15 mentioned "...distance education cannot be completely adequate and efficient on its own..." Viewing the 
category of ineffective feedback, seven participants stated that online foreign language classes were ineffective in terms of students' feedback. For example, P2 expressed by addressing the asynchronous classes that "...we cannot ask questions to our teachers about subjects we did not understand...", and P8 noted "...we, students, could not remember the information we receive from our teachers. I could not ask and discuss the topics..." Inferring from the category of lack of concentration, six participants declared that they had concentration problems in online foreign language classes during the pandemic. For example, P8 mentioned that "...I experienced stress because my motivation also decreased... I was reluctant to do the homework that had to be submitted... I did not feel like a student...”, and P14 said, "...it was difficult to focus on the lessons..." Deducing from the category of lack of self-discipline, four participants revealed that lack of self-discipline caused problems in online foreign language classes during the pandemic. For example, P6 said, “...You must have time management skills to benefit from online education...", and P10 affirmed that "...online education requires self-discipline...students have to make their study plan..." Relating to the last category, health problems, two participants stated that online foreign language classes could cause health problems during the pandemic. For example, P2 expressed that “...online lessons affect our physical health. Lessons take a long time and we sit in front of the screen for a long time. This harms our eyes and back as other technological devices..." and P16 mentioned, "...students and lecturers may have health problems due to the long-term computer use..."

The last research question probed into Turkish EFL learners' preferences regarding online foreign language classes. The participants' responses were categorized into "In favour" and "Not in favour". The distributions of the participants into categories were given in the following table (Table 3):

Table 3

Preferences of Turkish EFL Learners Regarding Online Foreign Language Learning

\begin{tabular}{lc}
\hline \multicolumn{1}{c}{ Categories } & \multicolumn{1}{c}{ Participants } \\
\hline In Favour & P2, P4, P6, P7, P11, P13, P19, P20 \\
Not in Favour & P1, P3, P5, P8, P9, P10, P12, P14, P15, P16, P17, P18 \\
\hline
\end{tabular}

According to Table 3, while eight participants were in favour of online foreign language classes, twelve participants were not in favour of online foreign language classes. Some of the participants who were in favour of online foreign language classes expressed, for example, that: P2: “...I think online education is very useful especially nowadays, but it is a system that we are not used to...", and P7: “...it is a great opportunity for families with financial difficulties..." Some of the participants who were not in favour of online foreign language classes mentioned, for example, that: P12: "...I do not like online education...I find face-to-face education more useful...", and P15: "...I do not believe that this form of education can replace formal training..."

Considering the findings, the features of availability, accessibility, costefficiency, time efficiency, comfort, personal speed, and being free from social pressure were defined as the advantages of online foreign language learning during the pandemic 
while lack of peer and social interaction, tech-related problems, mode of learning, ineffective feedback, lack of concentration, lack of self-discipline, and health problems were found out as the disadvantages of online foreign language learning during the pandemic according to the responses gathered from the participants.

\section{Discussion}

The findings of the current study regarding Turkish EFL learners' perceptions of the advantages of online foreign language learning revealed seven categories as availability, accessibility, cost-efficiency, time efficiency, comfort, personal speed, and free from social pressure. Several of these findings supported the findings of previous research studies in the literature. For example, cost-efficiency emerged as an advantage of online language classes in the current study. This category was supported by Casey (2008), who stated that online distance education provides viable and cost-effective training for higher education institutions. Considering the other expenses of university education such as accommodation, commuting, stationery, and nutrition, online foreign language classes may prevail over traditional face-to-face classes in this respect. Two participants (P12, P17) in the current study expressed that they felt free from social pressure and were engaged better in the tasks of online foreign language classes compared to the traditional face-to-face classes. Especially introverted students may express themselves better and participate more in online foreign language classes compared to extroverted ones. Previous research reported that the learners with more positive attitudes towards the Internet were inclined to participate more in the online forums, and the students who were self-efficient on the Internet performed better engagement in online learning tasks (Coffin \& MacIntyre, 1999; Tsai \& Tsai, 2003; Yang \& Lin, 2010). Availability and accessibility of online foreign language classes were expressed as advantages by most of the participants of the current study. Accordingly, Allo (2020) said that the Internet made classes available and accessible for EFL learners during the pandemic though they were physically away from their institutions. The Internet facilitated most of the students to follow their classes without interruption either in synchronous mode or in asynchronous mode during the pandemic. Furthermore, time efficiency, comfort, and personal speed may be foregrounded as other advantages that online education provides for students. These features posed by the education of this mode may save the students' time by supplying them the opportunity to join their classes from their comfort zones without any journeys that would otherwise consume their time and energy. Additionally, this type of education may lead the students to cover topics in line with their speeds related to their learning processes in the cases of an asynchronous mode of delivery.

Turkish EFL learners' perceptions of the disadvantages of online foreign language learning indicated seven categories: lack of peer and social interaction, techrelated problems, mode of learning, ineffective feedback, lack of concentration, lack of self-discipline, and health problems. The current study reported a lack of peer and social interaction as a disadvantage of online foreign language learning. Similarly, previous studies in the literature stressed the importance of active participation and negotiation in language learning (Alavi, 1994; Ellis, 1997; Shaw, 2013). Student interactions regarding cooperation and collaboration during course activities in face-to-face classes may enhance students' productive skills, which may not be as available as in online 
education. Also, technology-related problems were reported as a disadvantage of online foreign language learning in the current study. Problems regarding technology and Internet connection were mentioned previously in the literature as a disadvantage (Barr \& Tagg, 1995; Hakami, 2020). Technical problems such as electricity and lack of Internet connection, which may arise during online classes in progress, might severely interrupt the teaching and learning process. The participants of this study underlined self-discipline as a disadvantage, and, accordingly, Barnard et al. (2009), who highlighted the importance of becoming an autonomous learner in online learning contexts, raised this issue previously. Following scheduled classes regularly in traditional education may be an incentive for students to join the classes and accomplish their requirements. However, online classes may not be as encouraging for them to follow their programs in a disciplined way. The current study participants stated the mode of learning in online foreign language learning as a disadvantage. This finding was supported by Juhary (2012), who stressed the importance of preparing resourceful and engaging lessons for learners. The online mode of education may pose problems for those who prefer learning in a multimodal way, which combines social interaction between peers and instructors, learner feelings, motives. In addition, only relying on digital resources in this mode can be regarded as a problem for some learners. Lastly, the participants expressed problems regarding getting feedback during the online foreign language classes, which overlaps with the previous findings. For example, Tuncay and Uzunboylu (2012) stipulated that teachers cannot deal with students' online assignments. Direct feedback from the instructors during the classes in progress or learning from mistakes of other learners may not be available in online classes as they are in traditional ones. Furthermore, students who are used to the conventional education system in which they are physically and socially active may experience a lack of concentration or health problems such as backache, neck ache, and so forth during online mode learning.

Lastly, more than half of the participants of this study expressed that they were not in favour of online foreign language classes, and this finding was also in line with the findings of previous studies in the literature, which suggested that online learning platforms cannot completely replace traditional face-to-face learning and can be benefited as supplementary tools for language learning to enhance performances of learners (Njenga \& Fourie, 2010; Shaw, 2012).

\section{Conclusion}

The current study investigated the perceptions of Turkish EFL learners of online foreign language learning during the COVID-19 pandemic. In this regard, the study focused on the advantages, disadvantages of online foreign language classes during the pandemic, and whether the learners prefer online foreign language classes or not. The results showed that availability, accessibility, cost-efficiency, time efficiency, comfort, personal speed, and being free from social pressure were the advantages of online foreign language classes while problems regarding peer and social interaction, technology, mode of learning, feedback, concentration, self-discipline, and health were disadvantages of online foreign language classes during the pandemic according to the participants. Furthermore, more than half of the participants (12 participants) expressed 
that they were not in favour of online foreign language classes and expected to shift to traditional face-to-face language classes after the pandemic.

\section{Implications}

Several pedagogical implications can be suggested for foreign language education contexts based on the findings of the current study. Designing activities that can enhance and focus on peer and social interactions among foreign language learners may help to overcome their interaction problems in online foreign language classes. Also, applying synchronous mode in online distance education instead of asynchronous mode may contribute to instant interaction among professionals and learners. Additionally, choosing user-friendly online platforms may eliminate concentration problems and be more engaging for the learners. Lastly, lecturers may design weekly detailed study programs for learners to follow, and in this way, they may help learners to become more self-disciplined and autonomous.

\section{Limitations}

The current study involved several limitations that can be eliminated in further research studies. For example, the study included only one of the departments, Gastronomy and Culinary Art, and only one of the grades, 2nd grade, at the faculty. Further research can be planned with different grades and departments to reveal the perceptions of EFL students during the pandemic. Furthermore, the data of this study were gathered only from qualitative design throughout the processes. Using a form only to collect data can be seen as a limitation in the study. The researcher could implement online interviews (e.g., via Zoom or Skype) to elicit more detailed answers from the participants to provide data triangulation. Quantitative design or mixed methods design can be projected in further research to study the different aspects of online EFL education during the pandemic.

\section{Conflicts of Interest}

The author declared no potential conflicts of interest with respect to the research, authorship, and/or publication of this article.

\section{Author Bio}

Erkan Yüce is an Associate Professor at the Faculty of Education of Aksaray University. He received his Ph.D. degree in English Language Teaching from Hacettepe University Graduate School of Educational Sciences in 2018. English Language Teaching, the CEFR, Curriculum and Instruction, ESP, and CBI are among his fields of interest. 


\section{References}

Alavi, M. (1994). Computer-mediated collaborative learning: an empirical evaluation. MIS Quarterly, 18(2), 159-174. https://doi.org/10.2307/249763

Allo, M. D. G. (2020). Is the online learning good in the midst of Covid-19 Pandemic? The case of EFL learners. Jurnal Sinestesia, 10(1), 1-10.

Altam, S. (2020). Influence of social media on EFL Yemeni learners in Indian Universities during Covid-19 Pandemic. Linguistics and Culture Review, 4(1), 3547. https://doi.org/10.37028/lingcure.v4n1.19

Atmojo, A. E. P., \& Nugroho, A. (2020). EFL classes must go online! teaching activities and challenges during COVID-19 Pandemic in Indonesia. Register Journal, 13(1), 49-76. https://doi.org/10.18326/rgt.v13i1.49-76

Barnard, L., Lan, W. Y., To, Y. M., Paton, V. O., \& Lai, S.-L. (2009). Measuring selfregulation in online and blended learning environments. The Internet and Higher Education, 12(1), 1-6. https://doi.org/10.1016/j.iheduc.2008.10.005

Barr, R. B., \& Tagg, J. (1995). From teaching to learning-a new paradigm for undergraduate education. Change: The Magazine of Higher Learning, 27(6), 12-26. https://doi.org/10.1080/00091383.1995.10544672

Berg, B. L., \& Lune, H. (2013). Qualitative research methods for the social sciences: Pearson new international edition. Pearson Education Limited.

Bestari, A. C. Y., Faiza, D., \& Mayekti, M. H. (2020). Instagram caption as online learning media on the subject of extended writing during pandemic of Covid-19. Surakarta English and Literature Journal, 3(1), 9-21. http://ejournal.unsa.ac.id/index.php/selju/article/view/359

Casey, D. M. (2008). A journey to legitimacy: The historical development of distance education through technology. TechTrends, 52(2), 45-51. https://doi.org/10.1007/s11528-008-0135-z

Coffin, R. J., \& MacIntyre, P. D. (1999). Motivational influences on computer-related affective states. Computers in Human Behavior, 15(5), 549-569. https://doi.org/10.1016/S0747-5632(99)00036-9

Creswell, J. W. (2012). Educational research: Planning, conducting, and evaluating quantitative and qualitative research. Pearson.

Creswell, J. W., \& Creswell, J. D. (2018). Research design: Qualitative, quantitative, and mixed methods approaches. SAGE Publications.

Creswell, J. W., \& Miller, D. L. (2000). Determining validity in qualitative inquiry. Theory into Practice, 39(3), 124-130. https://doi.org/10.1207/s15430421tip3903\_2

Ellis, R. (1997). SLA and language pedagogy: An educational perspective. Studies in Second Language Acquisition, 19(1), 69-92. http://www.jstor.org/stable/44488668

Fansury, A. H., Januarty, R., Rahman, A. W., \& Syawal. (2020). Digital content for millennial generations: Teaching the English foreign language learner on COVID19 Pandemic. Journal of Southwest Jiaotong University, 55(3). https://doi.org/10.35741/issn.0258-2724.55.3.40

Hakami, M. (2020). Using Nearpod as a tool to promote active learning in higher education in a BYOD learning environment. Journal of Education and Learning, 9(1), 119. https://doi.org/10.5539/jel.v9n1p119 
Handayani, F., \& Handayani, N. D. (2020). The potential of online writing tools for EFL university students during the Covid-19 Pandemic. Journal of English Education, 6(1). 9-18. https://doi.org/10.30606/jee.v6i1.406

Harida, E. S. (2020). Students' learning in Corona virus diseases 2019 (Covid-19) situation. English Education: English Journal for Teaching and Learning, 8(1), 2537. http://jurnal.iainpadangsidimpuan.ac.id/index.php/EEJ

Hartshorn, K. J., \& Mcmurry, B. L. (2020). The effects of the COVID-19 Pandemic on ESL learners and TESOL practitioners in the United States. International Journal of TESOL Studies, 2, 140-156. https://doi.org/10.46451/ijts.2020.09.11

Juhary, J. (2012). Online comments for language learning: a pilot study. Procedia Technology, 1, 297-302. https://doi.org/10.1016/j.protcy.2012.02.063

Kanno, M. (2020). Maintaining and enhancing students' collaborative learning in a Japanese EFL higher education context. Journal of Education, Innovation, and Communication, Special Issue, 91-106. https://doi.org/10.34097/jeicom_SP_june2020_4

Knight, S. W. P. (2020). Establishing professional online communities for world language educators. Foreign Language Annals, 53(2), 298-305. https://doi.org/https://doi.org/10.1111/flan.12458

Layali, K., \& Al-Shlowiy, A. (2020). Students' perceptions of e-learning for ESL / EFL in Saudi Universities and their implications during Coronavirus Pandemic: A review of literature. International Journal of English Language \& Translation Studies, 8(1), 64-72. http://www.eltsjournal.org/archive/value8\%20issue1/9-8-120.pdf

Lee, A. R., \& Bailey, D. R. (2020). Learning from experience in the midst of covid-19: Benefits, challenges, and strategies in online teaching. Call-Ej, 21(2), 176-196. http://callej.org/journal/21-2/Bailey-Lee2020.pdf

Lomicka, L. (2020). Creating and sustaining virtual language communities. Foreign Language Annals, 53(2), 306-313. https://doi.org/10.1111/flan.12456

Merriam, S. B. (2009). Qualitative research: A guide to design and implementation. John Wiley $\backslash \&$ Sons.

Njenga, J. K., \& Fourie, L. C. H. (2010). The myths about e-learning in higher education. British journal of educational technology, 41(2), 199-212. https://doi.org/10.1111/j.1467-8535.2008.00910.x

Patton, M. Q. (2002). Qualitative research and evaluation methods. Sage.

Scott, D., \& Morrison, M. (2007). Key ideas in educational research. Bloomsbury Academic.

Shaaban, S. S. A. (2020). TEFL professors' e-learning experiences during the Covid 19 pandemic. European Journal of Foreign Language Teaching, 5(1), 82-97. https://doi.org/10.46827/ejfl.v5i1.3202

Shahzad, S. K., Hussain, J., Sadaf, N., Sarwat, S., Ghani, U., \& Saleem, R. (2020). Impact of virtual teaching on ESL learners' attitudes under COVID-19 circumstances at post graduate level in Pakistan. English Language Teaching, 13(9), 1-9. https://doi.org/10.5539/elt.v13n9p1 
Shaw, R. S. (2012). A study of the relationships among learning styles, participation types, and performance in programming language learning supported by online forums. Computers \& Education, 58(1), 111-120. https://doi.org/10.1016/j.compedu.2011.08.013

Shaw, R. S. (2013). The relationships among group size, participation, and performance of programming language learning supported with online forums. Computers \& Education, 62, 196-207. https://doi.org/10.1016/j.compedu.2012.11.001

Thorne, S. (2000). EBN notebook data analysis in qualitative research. EBN Notebook, 3, 68-70. https://doi:10.1136/ebn.3.3.68

Tsai, M. J., \& Tsai, C. C. (2003). Information searching strategies in web-based science learning: the role of internet self-efficacy. Innovations in Education and Teaching International, 40(1), 43-50. https://doi.org/10.1080/1355800032000038822

Tuncay, N., \& Uzunboylu, H. (2012). English language teachers' success in blended and online e-learning. Procedia - Social and Behavioral Sciences, 47, 131-137. https://doi.org/10.1016/j.sbspro.2012.06.626

World Health Organization [WHO]. (2020a). Novel Coronavirus (2019-nCoV) SITUATION REPORT-1. Accessed 16 September, 2020. https://www.who.int/docs/default-source/coronaviruse/situation-reports/20200121sitrep-1-2019-ncov.pdf?sfvrsn=20a99c10_4

World Health Organization [WHO]. (2020b). Novel Coronavirus (2019-nCoV) SITUATION REPORT-22. Accessed 16 September, 2020. https://www.who.int/docs/default-source/coronaviruse/situation-reports/20200211sitrep-22-ncov.pdf?sfvrsn=fb6d49b1_2

Yang, Y., \& Lin, N. C. (2010). Internet perceptions, online participation and language learning in Moodle forums: A case study on nursing students in Taiwan. Procedia Social and Behavioral Sciences, 2(2), 2647-2651. https://doi.org/10.1016/j.sbspro.2010.03.388

Yi, Y., \& Jang, J. (2020). Envisioning possibilities amid the COVID-19 pandemic: Implications from English language teaching in South Korea. TESOL Journal, 11(3), 1-5. https://doi.org/10.1002/tesj.543

This is an Open Access article distributed under the terms of the Creative CommonsAttributionNonCommercial-ShareAlike 4.0 International (CC BY-NC-SA 4.0). For further information, you can refer to https://creativecommons.org/licenses/by-nc-sa/4.0/ 